\title{
RESUME PENERAPAN AUDIT SISTEM DALAM AUDIT SISTEM INFORMASI
}

\author{
Ni Wayan Damayanti \\ 175100013 \\ Universitas Mitra Indonesia Sistem \\ Informasi \\ wayandamayanti.student@umitra.ac
}

$\underline{. i d}$

\begin{abstract}
Sangat penting auditor memahami tujuan tersebut sebelum menjalankan audit.

Rencana audit yang terstruktur dan terdokumentasi mengidentifikasi dan menetapkan kriteria bagaimana menilai keberhasilan audit. Manfaat Rencana Audit Perencanaan merupakan salah satu teknik manajemen yang paling pokok tetapi merupakan salah satu yang paling buruk penerapannya. Sebuah audit disebut efektif apabila tujuan nya tercapai.
\end{abstract}

Kata Kunci :Audit, Sistem.

\section{A. PENDAHULUAN}

Audit berasal dari bahasa latin "audire" yang berate mendengar atau to hear. Yang artinya apabila seseorang pemilik organisasi usaha merasa ada suatu kesalahan atau penyalahgunaan, maka ia mendengarkan kesaksian orang tertentu (Sanyoto, 2017),

$\begin{array}{lr}\text { Audit sistem } & \text { informasi } \\ \text { merupakan } & \text { proses } \\ \text { pengumpulan } & \text { dan } \\ \text { pengevaluasian } & \text { bukti-bukti } \\ \text { untuk menentukan apakah suatu } \\ \text { sistem aplikasi } & \text { komputerisasi }\end{array}$




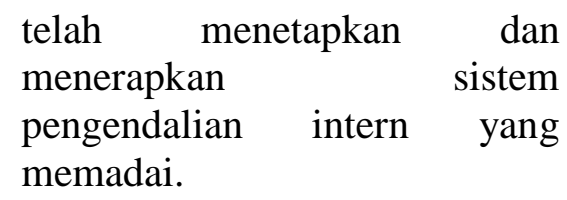

\section{PEMBAHASAN / STUDI KASUS}

Deskripsi dan Analisa

Pengendalian Internal.

Apakah pengendalian internal ada?

Apakah pengendalian internal tersebut efektif? Pengujian terbatas dapat dilakukan untuk menilai efektifitas nya.

Penilaian ulang resiko dapat dilakukan pada tahap ini.

Pengujian terhadap

Pengendalian Internal.

Untuk memastikan

pengendalian internal benar efektif haruslah dilakukan pengujian.
Pengujian ini nantinyaa kan dituangkan pada laporan hasil audit.

Contoh pengujian yang dapat

Dilakukan:

Pemeriksaan berkas dan dokumen;

Wawancara dengan pihak manajemen atau personil lain;

Pengamatan terhadap operasional;

Pemeriksaan aset;

Pemeriksaan berkas

komputer;

Komparasi hasil audit dengan laporan auditee.

Temuan dan Rekomendasi.

Temuan audit terdiridari 4 (empat) bagian yaitu kriteria, kondisi, akibat dan penyebab. Rekomendasi, umumnya berbentuk:

Tidak menyarankan perubahan pada sistem pengendalian. Peningkatan pengendalian untuk mengurangi resiko.

Pemindahan resiko kepihak luar (pada kondisi dimana resiko cukup tinggi tetapi pengendalian sulit dilakukan 
atau tidak ekonomis) misal:

asuransi, alihdaya.

Laporan Hasil Audit.

1. Laporan hasil audit hendaknya diselesaikan tepat waktu.

2. Laporan hasil audit didokumentasikan dan dikomunikasikan kepada auditee.

3. Auditee diminta untuk memberikan tanggapan dan tanggapan akan dimasukkan ke laporan hasil audit final. Hal ini untuk memastikan objektifitas audit.

Tindak Lanjut.

Tahapan untuk memastikan apakah manajemen setelah mengetahui rekomendasi:

- Menerima resiko, tanpa perbaikan;

- Tidak menerima resiko, tanpa perbaikan;

- Melakukan langkah-langkah untuk mengendalikan kelemahan.
Evaluasi Audit.

Merupakan tahapan final dimana auditor menilai proses audit yang telah dilakukan. Langkah ini sering diabaikan, sehingga mengakibatkan audit di masa berikutnya tidak optimal.

\section{KESIMPULAN}

Dari pembahasan yang saya buat perencanaan dalam audit sistem informasi sangat disarankan karena tahap tahap dalam perancanaan itu sebagai ladasan dalam menyelesaikan suatu masalah yang berkaitan dengan audit sistem informasi. Ini juga sangan efektif karena bisa membangun rencana dengan sangat matang. Pada tahap akhir perencanaan adanya evaluasi sangat berguna karena Merupakan tahapan final dimana auditor menilai proses audit yang telah dilakukan. Langkah ini sering diabaikan, sehingga mengakibatkan audit di masa berikutnya tidak optimal. 


\section{E. DISKUSI}

Setelah saya membaca dan membahas perencanaan audit sistem informasi ini melalui beberapa buku, sumber, dan media baca lainnya tahap perencanaan pada audit sistem informasi ini sangat menguntungkan sebab banyak beberapa tahapan dalam perencanaan yang sangat mendetail dalam mengambil keputusan akhir sehingga minim nya kesalahan yang akan muncuk atau masalah lainnya. Pada tahap akhir di dalam perencanaan adanya evaluasi sehingga kinerja kedepannya dapa lebih optimal di bandingkan dengan yang telah dikerjakan sebelumnya. Saya yakin hal ini sangat berguna bagi seluruh bagian dalam menyelesaikan masalah nya terutama di dalam bidang audit sistem informasi.

\section{F. REFERENCE}

[1] O. M. Febriani and A. S. Putra, "Sistem Informasi Monitoring Inventori Barang Pada Balai Riset Standardisasi Industri Bandar Lampung," J. Inform., vol. 13, no. 1, pp. 90-98, 2014.

[2] A. S. Putra, "Paperplain: Execution Fundamental Create Application With Borland Delphi 7.0 University Of Mitra Indonesia," 2018.
A. S. Putra, "2018 Artikel

[4]

Struktur Data, Audit Dan Jaringan Komputer," 2018.

A. S. Putra, "ALIAS MANAGER USED IN DATABASE DESKTOP STUDI CASE DB DEMOS."

[5] A.

S. Putra, "COMPREHENSIVE SET OF PROFESSIONAL FOR DISTRIBUTE COMPUTING."

[6] A. S. Putra, "DATA ORIENTED RECOGNITION IN BORLAND DELPHI 7.0."

[7] A. S. Putra, "EMBARCADERO DELPHI XE 2 IN GPUPOWERED FIREMONKEY APPLICATION."

[8] A. S. Putra, "HAK ATAS KEKAYAAN INTELEKTUAL DALAM DUNIA TEKNOLOGY BERBASIS REVOLUSI INDUSTRI 4.0."

[9] A. S. Putra, "IMPLEMENTASI PERATURAN PERUNDANGAN UU. NO 31

TAHUN 2000 TENTANG DESAIN INDUSTRI

BERBASIS INFORMATION TECHNOLOGY."

[10] A. S. Putra, "IMPLEMENTATION OF PARADOX DBASE.”
[11] A. S. Putra, "IMPLEMENTATION OF TRADE SECRET CASE STUDY SAMSUNG MOBILE PHONE."

[12] A. S. Putra, "IMPLEMENTATION

PATENT FOR APPLICATION WEB BASED CASE STUDI WWW. PUBLIKLAMPUNG. COM." 
SYSTEM FIRST TO INVENT IN DIGITALLY INDUSTRY."

[14] A. S. Putra, "MANUAL REPORT \& INTEGRATED DEVELOPMENT ENVIRONMENT BORLAND DELPHI 7.0."

[15] A. S. Putra, "PATENT AS RELEVAN SUPPORT RESEARCH."

[16] A. S. Putra, "PATENT FOR RESEARCH STUDY CASE OF APPLE. Inc."

[17] A. S. Putra, "PATENT PROTECTION FOR APPLICATION INVENT."

[18] A. S. Putra, "QUICK REPORT IN PROGRAMMING.'

[19] A. S. Putra, "REVIEW CIRCUIT LAYOUT COMPONENT

REQUIREMENT ON ASUS NOTEBOOK."

[20] A. S. Putra, "REVIEW TRADEMARK PATENT FOR INDUSTRIAL TECHNOLOGY BASED 4.0."

[21] A. S. Putra, "TOOLBAR COMPONENT PALLETTE IN OBJECT ORIENTED PROGRAMMING."

[22] A. S. Putra, "WORKING DIRECTORY SET FOR PARADOX 7."

[23] A. S. Putra, "ZQUERY CONNECTION

IMPLEMENTED

PROGRAMMING STUDI CASE PT. BANK BCA Tbk."

[24] A. S. Putra, D. R. Aryanti, and I. Hartati, "Metode SAW (Simple Additive Weighting) sebagai Sistem Pendukung Keputusan Guru Berprestasi (Studi Kasus:
SMK Global Surya)," in Prosiding Seminar Nasional Darmajaya, 2018, vol. 1, no. 1, pp. 85-97.

[25] A. S. Putra and O. M. Febriani, "Knowledge Management Online Application in PDAM Lampung Province," in Prosiding International conference on Information Technology and Business (ICITB), 2018, pp. 181-187.

[26] A. S. Putra, O. M. Febriani, and B. Bachry, "Implementasi Genetic Fuzzy System Untuk Mengidentifikasi Hasil Curian Kendaraan Bermotor Di Polda Lampung," SIMADA (Jurnal Sist. Inf. dan Manaj. Basis Data), vol. 1, no. 1, pp. 21-30, 2018.

[27] A. S. Putra, H. Sukri, and K. Zuhri, "Sistem Monitoring Realtime Jaringan Irigasi Desa (JIDES) Dengan Konsep Jaringan Sensor Nirkabel," IJEIS (Indonesian J. Electron. Instrum. Syst., vol. 8, no. 2, pp. 221-232.

[28] D. P. Sari, O. M. Febriani, and A. S. Putra, "Perancangan Sistem Informasi SDM Berprestasi pada SD Global Surya," in Prosiding Seminar Nasional Darmajaya, 2018, vol. 1, no. 1, pp. 289-294. 